\title{
Severe Head Injury Sequelae caused in humans
}

\section{Traumatismo Craneoencefálico Severo. Secuelas ocasionadas en el ser humano}

CORTÉS-ALVAREZ, Yolanda†*, ESTRELLA-VELÁZQUEZ, Rafael, GONZALEZ-NERI, Aarón Iván and QUEZADA-MORENO, Maribel

Universidad Autónoma de Querétaro, Faculty of Accounting and Administration, Campus San Juan del Río.

ID $1^{\mathrm{er}}$ Autor: Yolanda, Cortés-Alvarez / ORC ID: 000-0002-0128-3415, CVU CONACYT ID: 595702

ID $1{ }^{\text {er }}$ Coautor: Rafael, Estrella-Velázquez, ORC ID: 0000-0003-3236-4397, Researcher ID Thomson: X-3105-2018, CVU CONACYT ID: 820405

ID $2^{\text {nd }}$ Coauthot: Aarón Ivan, González-Neri / ORC ID: 0000-0002-4082-0746

ID $3^{\text {rd }}$ Coauthor: Maribel, Quezada-Moreno

DOI: $10.35429 / J H R T .2019 .16 .5 .35 .43$

Received: July 30, 2019; Accepted: December 20, 2019

\begin{abstract}
This research points out how valuable the brain in humans is, it indicates from the definition of the word brain, of the nervous system, composition of the skull, parts of the brain, responsibilities of the brain, actions to keep the brain in good shape, the power that he has the brain and the senses that he indicates himself. There is a case study of an accident that caused a severe craniocerebral trauma teacher and the sequelae that will already be part of her teacher's daily life and the knowledge that these sequelae may continue to appear during the 3 years of the accident. It also presents the progress that has been achieved over 10 months of recovery, this with the aim of creating awareness in people and understanding how important the brain is to continue living in this magnificent world.
\end{abstract}

\section{Brain, Severe Craniocerebral Trauma, Teacher}

\begin{abstract}
Resumen
Esta investigación señala lo valioso que el cerebro en el ser humano es, indica desde la definición de la palabra cerebro, del sistema nervioso, composición del cráneo, partes del cerebro, responsabilidades del cerebro, acciones para mantener al cerebro en buena forma, el poder que tiene el cerebro y los sentidos que indica él mismo. Se tiene un estudio de caso de un accidente que ocasionó a una maestra trauma craneoencefálico severo y las secuelas que ya serán parte de su vida diaria de la maestra y el saber que durante los 3 años del accidente pueden continuar apareciendo estas secuelas. Se presenta también el avance que se ha logrado a lo largo de 10 meses de recuperación, esto con el objetivo de crear conciencia en la gente y que se comprenda lo importante que es el cerebro para continuar con vida en este magnífico mundo.
\end{abstract}

Cerebro, Trauma Craneoencefálico Severo, Maestra

Citation: CORTÉS-ALVAREZ, Yolanda, ESTRELLA-VELÁZQUEZ, Rafael, GONZALEZ-NERI, Aarón Iván and QUEZADA-MORENO, Maribel. Severe Head Injury Sequelae caused in humans. Journal of Human Resources Training. 2019, 516: $35-43$

$\dagger$ Researcher contributing first Author 


\section{Introduction}

As a result of an accident caused by an articulated tractor-trailer with a cage-type semitrailer that carried corn, where the teacher's vehicle was below the semi-trailer. (IMSS, F0637, 09/27/2018)

Diagnostic impression of the affected.

The diagnostic impression was to suffer serious injuries of cerebral contusion with loss of alertness, accident on the Mexico-Querétaro highway. TBI - severe craniocerebral trauma with severe cerebral edema (severe craniocerebral trauma. This damage is the most frequent cause of brain damage. TBI and if it is indicated to be severe, even more than trauma, the damage is immeasurable). (IMSS, F0637, 09/27/2018), (Torres 2002). For the author Halire, (2019) The TCE is defined as a head injury with at least altered consciousness and / or amnesia due to trauma and is constituted as the 1 st.

Cause of death in the young population, the 3rd., In the entire population and it is also known that the deranged sequelae of cranioencephalic trumatism are not always visible, mainly those of the cognitive type, and then this trauma can be referred to as a silent epidemic. And by this circumstance it was defined that it was necessary to continue this case study and be able to share the progress with those who experienced this damage.

So it is extremely important for people to know how the brain in the human being is a fundamental part of continuing with life in this world. What better, to know of a case study that had been detached from an accident on the Mexico-Querétaro highway and that it has been given the necessary follow-up to continue step by step the progress in this aspect and share knowledge with all human beings, because being men, women, girls, boys, you can fall into a situation of this magnitude. And even more knowing that the TCE is mainly due to traffic accidents -70/80\% -, falls -10/15\% -, and attacks Peden, Cols, (2012).

Imagining the word sequel would not mean much, however, seeing everything that can cause the human being should be prepared and with the knowledge about it.

\section{Severe Head Injury Sequelae caused in humans}

Definition of Central Nervous System. (Lambert, 2010)

Our Central Nervous System is formed by the brain and spinal cord. In addition, the central nervous system is protected by the skull that includes: the brain, cerebellum and spinal bulb.

Brain + Spinal Cord $=$ Central Nervous System Central Nervous System $=$ Our Skull

Protected by:

Our Skull includes: - Our Brain

-Our cerebellum

-Our medulla

The brain: it is the most complex structure of the human organism, it has one hundred billion nerve cells (Lambert, 2010) and is our main nerve center; its different areas are primarily responsible for:

a) The movement: Without the Telecephalus, the body could not move (Greathouse, 2011)

b) Emotions and perceptions (Greathouse, 2011)

Your brain makes you feel:

-Sad. When you can't go dancing

-Happy. Because your birthday is coming.

c) The conduct. It is who says that you love your family, it is not your heart that dictates it to you. in the brain.

Higher mental functions are carried out

The brain understands what is observed after the ocular nerves send a message to the brain.

The brain is strengthened every time something is learned.

The brain is strengthened every time something is practiced. Therefore, every time something is repeated, things get better.

The brain is working even when the human being is found asleep, that's why you have dreams.

CORTÉS-ALVAREZ, Yolanda, ESTRELLA-VELÁZQUEZ, Rafael, GONZALEZ-NERI, Aarón Iván and QUEZADA-MORENO, Maribel. Severe Head Injury Sequelae caused in humans. Journal of Human Resources Training. 2019 


\section{Parts of the brain}

1. Telencephalon: Largest part of the brain. It is responsible for thinking, helps to move the body, without this part of the brain you could not hit a baseball or solve a mathematical problem.

2. Brain Trunk: The person in charge of breathing. It tells the heart to pump more blood when it starts running. He even asks the stomach to defer lunch.

Actions to keep a brain in good shape:

1. Eat healthy food

2. Exercise a lot

3. Sleep a lot

4. Read

5. Play music

6. Do not use drugs or alcohol

\section{Brain power}

The brain is the head of the whole body because:

1. Store all memories

2. Indicate what should be said and done

3. It keeps the body alive

If the human being takes care of his brain, the brain will take care of the human being and his senses:

\section{Senses of the human being (Lambert, 2010)}

The following five senses are identified:

$\begin{array}{ll}\text { 1. } & \text { View } \\ \text { 2. } & \text { Ear } \\ \text { 3. } & \text { Touch } \\ \text { 4. } & \text { Odor } \\ \text { 5. } & \text { Flavor (taste) }\end{array}$

A neuroscientific doctor transforms the way of thinking about the brain, health and personal happiness. In this regard to reveal the powerful connection between exercise, learning, memory and cognitive skills, International Neuroscientist Suzuki learned how to protect herself from stress, negative thoughts, traumas and addictions. She considers herself a living example of neuroscience, because everything she did to her body was changing her brain. (Suzuki, et. Al. 2016).
This considered from his perspective as a neuroscientist that led her to discover that -Using the brain is to achieve happiness-. Suziki currently works at the University of New York NYU-, of the United States of America. He not only teaches courses for Neuroscience students that incorporate exercise into this class and teaches a free exercise class every week open at NYU.

Near the 40th birthday, Dr. Wendy Suzuki, an expert in Neuroscience, was in the highest part of her profession. Winner of awards for being of high quality in her high prestige skills as a university professor. To celebrate her 40th birthday, she wrote a book on an adventure trip that forced her to rise against her reality to think about her professional success. She was overweight, she was a lonely, tired woman and she knew that her life had to change. Then he started simply - going to an exercise class, he eventually noticed an improvement in his memory, his energy levels and his ability to work quickly and move from activities or tasks to tasks and activities easier to perform.

Not only began to exercise, but also being more energy and his memory improved starting with a class and she, as a neuroscientist wanted to know why this progress. Because if she transformed her body and life, now she could transform that of others.

This scientist continued with her project herself and discovered that there is a biological connectivity between exercise, mindfulness and action. With exercise, the body feels more lived, the brain will work better. A human being can be made smarter. And the results of the project showed Suzuki (2016) that it can occupy the mind, improve memory, the ability to learn new skills and better functioning.

The brain is the structure that defines how it looks, feels, tastes, smells and is heard as Lambert (2010) expresses it in its five senses of the brain it mentions. These senses developed in the world around us. In addition, the above defines personalities and allows us to go from crying to laughter and sometimes backwards in our eyes. 
The brain is the structure that defines how it looks, feels, tastes, smells and is heard as Lambert (2010) expresses it in its five senses of the brain it mentions. These senses developed in the world around. In addition the above defines personalities and allows you to go from crying to laughter and sometimes backwards in our eyes.

\section{Methodology approach}

For Hernández and Mendoza (2018) to start this work, the problem was identified, once the above, the study was delimited. And the methodology that are the methodological bases that must be adopted to carry out the research. When considering this problem as an investigation, it was defined that the method to be followed would be the qualitative one, since it involves aspects such as: considering different existing approaches. This project is also located in the area of social sciences. And in qualitative research a deep understanding of human commitment and the reasons for the different aspects of such behavior are required. In other words, this qualitative method investigates why and how a decision was made, as well as supported by small samples, is the technique of observing small population groups, such as classrooms, municipalities, an organization, or a person, as is the case in this study.

Balcazar (2005: 54) A person in an educational institution. For Ruiz Olabuenaga (1999: 11) the qualitative techniques that this research seeks is to a) describe and understand the detailed means through which the subject embarks on meaningful actions and creates a world of his own and that of others. B) in-depth descriptions were also made. This work was also located as a case study, since it will be the intense exploration of a study unit that can be considered, a person, family, municipality, community or institution and then a person will be located in an institution.

And it was hoped that as Burns (2010: 221) identifies it as a good source of descriptive information and that it will be evidence to support the theories or to invalidate them. And it is expected to find findings. Considered as a descriptive and explanatory case study according to Yin (1993: 5). For validity, it will be carried out with the existing contact of the specialists and the subject of study according to as stated by Suárez (2002).

\section{Results}

The researcher found herself hospitalized in two different hospitals before being discharged and moving her father's house.

The second time he was in the hospital from October 11 to 19 of the same month in the second hospital.

Later he became aware of her being at the beginning of December 2018.

Discharged by the IMSS on February 26, 2019. He was never given a copy of his discharge, he was only informed that on the 26th he would present himself to his work in a normal way.

It was very interesting to listen to the person affected with severe head skull trauma and who today recognizes that life can only be understood backwards, but you have to live it forward, since as you know, when there is certainly a lasting change, as the trauma he suffered is about to mark the life of a person. He also managed to share that today he understands that life has white moments Paver (2019) and blacks Jauregui (2008: 166) and oneself decides which color can give more weight, greater importance, because if it were located in these colors with the wolf animal , Jordan (2010) then the black wolf demonstrates the person's ego, anger, negative things.

The white wolf demonstrates essence, sympathy, is where the essence develops, the values, the virtues, positive things, part of what oneself is. If you decide to feed the white wolf it will make you stronger and the human being should not get on the septum because suddenly he can get dizzy and fall. He also managed to understand that life is too short to worry about silly things, should human beings have fun, fall in love, not regret this, or allow others to turn off the light with which the human being shines.

The author Paver (2019: 23) mentions that wolves are very similar to human beings, that they can be identified and differentiated without much difficulty to each of the members of the 23 different species that exist and that are distributed throughout the half the north of the planet and whose weight for the males of this animal is between 40 and $70 \mathrm{~kg}$. 
And females, 20\% lighter than males between 32 and $55 \mathrm{~kg}$ are identified. However, as an effect of individual variability of these animals, there are the following cases considered as exceptions to the weights mentioned above and these weights belong to wolves that were already captured.

a. $\quad 80 \mathrm{~kg}$ In North America.

The colors of these wolves are according to the author Jordan (2010: 18) White wolves. Gray Wolves Brown Wolves Red Wolves

The colors of Eurasian wolves: White and gray wolves. Brown Wolves and Red Wolves

b. $\quad 96 \mathrm{Kgs}$. En Cárpatos

c. $\quad 75$ kgs. En Rumania

A wolf can live between 13 and 14 years in captivity and in the wild it is very difficult for them to reach that age. It does not allow them to continue living the constant harassment of the human being and the progressive destruction of the natural inhabitants, these two actions have a very negative influence on their condition of continuing to live.

The deterioration of dentures in wolves begins at 10 years of age.

Canid wolves are specially adapted to the race, specialized in jogging, which is a not very fast march but can be maintained for a long time.

The wolves are able to maintain a regular pace of walking for many hours without interrupting it and can reach up to $100 \mathrm{~km}$. Kilometers- A night away.

The wolf according to Jordan (2010: 24) in his persecutions reaches a maximum speed of 40-45 km / hr. -kmometers / hours- And its prey surpasses it in:

a) Deer:

$65 \mathrm{~km} / \mathrm{hr}$.

b) Hares and fallow deer: $60 \mathrm{~km} / \mathrm{hr}$.

c) Mouflon: $50 \mathrm{~km} / \mathrm{hr}$.

The tail of the wolves is between 30 and $40 \mathrm{cms}$. The height of agreement to the shoulders of a human being is between 60 and $90 \mathrm{~cm}$. The length of the body, only from the head to the trunk is 110 to $140 \mathrm{~cm}$.
Characteristics are very similar to those of the human being in relation to the hair, since the wolf's hair adapts to the environment and the climate from where it develops its life, due to this species it presents notable racial and individual differences.

In addition, it is indicated that the anatomical and psychological diversity of the wolf is reminiscent of that of the human species, where the facial features, height, skin tone and behavior are greatly varied throughout the planet. Jordan (2010: 23)

Life must be understood as a challenge and challenges will always lead to decision making. That is very valuable for human beings. The best thing to think and make good decisions is:

a) Know that there are limits. But from today, now on. there are no limits

b) Having enough guts for everything.

You should have considerations around and know their functions, one of them could move forward or backward. In terms of the values of peace and self-esteem, what was heard on September 6, 2018, was heard at the beginning of the year meeting at the school of his son, the affected TCE Severo.

Don't have to feel bad if you make one mistakes.

Always you will learn

- $\quad$ You always think positively.

With this you can have a better attitude towards life, a beauty of soul and connection with the other beings that surround the human being, apart from knowing better who we are, accepting who we are, how we are, with this you will dress to accept yourself yourself, you will love yourself.

He also understands that the type of character does not work for people who do not bother them and suffer. In 1962 the experiment was carried out that revealed that the existence is a brief crack of light between two obscurities. There was also the obedience experiment in 1970. The domino effect is activated when assuming the role of the teacher. 
There is a little awareness of who the teacher is at the beginning of December, having a first consultation with a neurologist in the municipality on December 7, 2018. To which he continued giving medication to finish the brain healing process.

Monday, December 31, 2018. Attendance at 1st. Appointment in the IMSS aware of knowing that it is the person who suffered the accident and requires attending a consultation to continue giving him his disability. Time: 3:00 p.m. UMF6, Office 10.

Tuesday, February 5, 2019 office appointment no. 10 of the IMSS in San Juan del Río, Qro.

Monday, February 25, 2019 ophthalmology discharged the issue of sight.

Monday, March 11, IMSS San Jaan del Río, takes an X-ray of the head to be consulted by the otolaryngologist and issue a diagnosis of his specialty.

March 20, happiness is increased by celebrating the international day of happiness. And the formula is taken to prepare the ground and flourish happiness.

1. Happiness is only in the here and now of the present moment.

2. Thank the difficult times.

3. The state of serving, sharing and loving

4. The healthier you are, the more you nourish your body and you are more in favor of happiness.

5. Have a positive thought. obligation.

Happiness is not only your right, but your

Formula:

Happiness $=$ Predisposition + Living conditions + Voluntary activities

$\mathrm{F}=\mathrm{P}+\mathrm{C}+\mathrm{A}$

So if you say: "I am happy", you should not put your happiness depending on another person.

If you don't want to be a dummy, you have to decide how you want to take the situation and how it will affect you.
March 25, 2019, IMSS registered, however, the interested party was not given a copy.

Friday, March 29, beginning of the IMSS Otolaryngologist treatment of Avamis drops and saline water washes.

May 5, finished application of treatment of drops of Avamys 27.5 at night.

Since the affected one had not understood that already at the beginning of the year there had been sequels of the Severe TBI, she was given the task of investigating why the smell, taste and taste had disappeared and created that perhaps she did not have enough zinc in the body so he investigated the following zinc.

Zinc is the nutritional element to increase the function of taste and taste.

There is no data on how much zinc is required in the body, nor how much is needed. The body's absorption is $20 \%$, which is done in the small intestine. The amount of $15 \mathrm{mg} /$ day is recommended daily. If zinc is not required to be absorbed, or should be eaten: red meat, whole grains, seafood, dairy products

Foods rich in zinc: Chickpeas, pumpkin seeds

Symptoms of a lack of zinc: a) Problems with the sense of taste

B) Problems with the sense of smell.

Products sold with zinc:-Nutrioli oil.

July 20, 2019. The affected one once appeared in the prosecutor's office of San Juan del Río to inform the prosecutor that he was still alive and could continue with the investigation since he attended to ratify his personality. And then the prosecutor asks him to appear for an expert medical review at the State Prosecutor to issue a certificate on the physical health of those who suffered severe brain skull trauma. 
It is important to consider that the doctor in turn uses the issuance of a certificate with two modalities: a) Informational, where it is mentioned that there is still no document that supports a sequel or physical disorder, or that a discharge by the IMSS of person. b) medical certificate indicating that there is no evidence that any doctor says that there are sequelae due to the severe craniocerebral trauma that occurred.

\section{Sequelae of severe craniocerebral trauma}

On July 20, 2019. The State Prosecutor's Office was assisted to carry out a medical consultation and dr. The person who checked the affected person was the doctor who attended the IMSS to check her physical condition on the day of her accident. The affected had the following questions: for the date of the appointment: 10 months after the accident.

1. Not remembering absolutely nothing on the day of the accident until he regains consciousness of who he is and knows at the time that he had an accident. (3 months after September 27, 2018). Can I wait how long I remember? Is it good__ Is it bad?

2. Not having the taste, smell and taste when feeding on anything or product or not perceiving any smell, even gas.

3. Do not count on balance. Not being able to move by herself, in such a way that she had to hire a physiotherapist to be able to have movements and recover body movement. But when climbing a ladder and seeing checkered floors you have to be extremely careful as the staircase or floor moves. When can this sequel be fixed?

4. To care for food, personal care (bathing, drying the body) provide and continue administering medications, etc. Nurses were hired to provide support regarding the necessary care that every living human being requires and is entitled to.

5. Not having enough balance to move freely and safely, especially when climbing stairs and stepping where there are pictures or uneven floors.

6. Not being able to drive Suddenly if I move I feel insecurity. Can it be by my sight? How long does it take for my vision if it considers that it could be considered as influencing this function?
7. Do not sleep as usual (sleep on the side) and sleep with two pillows, because if you do not use a pillow the right eye dawns more irritated than the left.

8. Do not breathe as it should, since you have a deviated septum. (turning 60 or 65 can be operated, not before. According to an ENT diagnosis). If I sleep on the right side, that right side of the nose becomes inflamed and the sufficient air that reaches the brain is not breathed, if I sleep on the left side, then the left side becomes inflamed and obstructs that between the amount of air that must enter to the brain Even in physical places with air conditioning you feel you don't have enough air.

9. It is uncomfortable to get in a car and put the air conditioning. You cannot breathe as usual. As both sides are inflamed and less air enters.

10. It was perceived at the beginning of the consciousness of who it was, with a double view. Where to see what was perceived doubled. Today only smaller letters closely are not perceived. Thing that never happened.

11. Not being able to run, just walking, not attending a gym to do classes or physical exercises that damage the brain. I used to exercise to keep myself physically fit, I used to run $5 \mathrm{~km}$. In the mornings

12. Click sensation when closing the right eye. (which was never experienced in advance in 50 years)

13. Aftermath that could occur during the 3 years following the day of the accident.

14. Including those that could appear to my son who was the one who accompanied me in my truck and also who was in that accident.

15. In how long does my brain look for an option to accommodate my nerves and if the sequel of taste, taste and lost smell remains, how long can I wait for it to come back?

16. From your perspective and experience, what would be the worst sequel that would appear in these two years and almost two months left? 
Dr. comments that he will issue his opinion to the prosecutor who is requesting it as an informative to give me more time to present a diagnosis or medical history of severe head-tohead trauma. since none of the documents that I carry indicate or mention the discharge and the sequels already appeared at the beginning of the year 2019. So it is necessary that the damaged present evidence for which they are having and that it is by specialist or IMSS because if the doctor Legista mentions them in his report, the prosecutor will ask him what documents he bases his opinion on and no one mentions that there is any sequel or that the person injured with severe TCE is already discharged.

It was then very evident that on July 22, the affected woman had no knowledge of the consequences she had in terms of the severe craniocerebral trauma she suffered, which made it necessary to have an appointment with the neurologist and until then knew that the function of taste, Odor and taste were indeed sequels caused by Severe TCE. And the balance was required to continue working to achieve it.

One of the foods that was consumed and provided perhaps good results was avocado. And conducting an investigation, it was found that consuming avocado daily has the following benefits:
a. Prevents bad breath.
b. Reduces tissue inflammation. Treat arthritis and deflate muscles
c. Fights nausea and vomiting caused by pregnancy. (Notmusa, 2019). students:

Important notes in Mexico to share with

According to the Pan American Health Organization (2019).

Every two hours a person dies in Mexico in a road accident.

The causes of accidents:
a) Cellular Use
b) Excessive speed (drinking alcohol)
c) Speed without alcohol

Breathalyzers are to save the lives of young people, who on the cell phone comment on where the breathalyzer is.
The greatest help is not the breathalyzer but the awareness of not taking when driving.

Mexico is the 7 th. Place in the world in road accidents.

24,000 Mexican people die a year. "If you drink do not drive"

\section{Conclusions}

It is very important to share the experience of this accident so that the human being knows that a minor blow that is in the brain could cause the death of the person and that there is a wonderful miracle every day to open the eyes and continue living In this wonderful world and as a professor-researcher, being able to continue in a classroom teaching can share the experience with future generations and raise awareness of how important the brain is in the human being. And that you should be aware that the severe TCE caused mainly by traffic accidents, falls and attacks. Penden, Cols (2012).

\section{References}

Balcazar, P. (2005) La Investigación Cualitativa. 1ª . Edición (pp. 54) México: Ed. Universidad Autónoma del Estado de México. Dowshen, E. (2018) El cerebro y el Sistema Newvioso. Teen Health. https://kidshealth.org/es/teens/brain-nervoussystem-esp.html

Greathouse, L. (2011) El cerebro. https://books.google.com.mx/books? $\mathrm{id}=\mathrm{WdHg}$ BAAAQBAJ\&dq=nervios+conectados+al+cere bro\&source $=g b s \_n a v l i n k s \_s \quad$ fecha de consulta en internet del libro 26 de junio, 2019

Halire, H., L. R. (2019) Factores Asoiados a mortalidad en pacietes con trumatismo craneoencefálico grave en el Hospital Antonio Lorena, Cusco 2016, 2018.

Hernández, R., Mendoza, C. (2018) Metodología de la Investigación: Las rutas cualitativa, cantitativa y Mixta. $6^{\mathrm{a}}$. Ed. México: Mc. Graw Hill. ISBN: 978-1-4562-6096-5

Instituto Mexicano del Seguro Social. (2018) Registro de accidente. 
Institut Guttman, Institut Univaersitari Ads crit a la UAB, Hospital de Neurorrehabilitación, fecha de consulta: junio 13, 2019. https://www.guttmann.com/es/hospital-

especializado-neurorrehabilitacion .

Institut Guttman, Institut Univaersitari Ads crit a la UAB, Hospital de Neurorrehabilitación,https://www.guttmann.co $\mathrm{m} / \mathrm{es} /$ treatment/traumatismo-craneoencefalicotce fecha de consulta : 13 de junio, 2019

Intituto Santiago (2018) Junta de inicio de año escolar $7^{\circ}$. Secumdaria.

Jauregui C. (2008) Canibalia: Canibalismo, Calibalismo, anropología cultura y consumismo en América Latina. Editorial Iberoamericna: Vervuert. Pag. 166

Jordan, F. (2010) La vida del lobo. Madrid, España:Ediciones Nobel, S. A. ISBN: 978-848476-664-3, pag. 18-23

Lambert, M. (2010) The Brain and Nervious System. Edition: Ilustrada, Silver Burdett Press. USA.

Paver, M. (2019) Wolf brother, chronicles of ancient darkness. A boy, a Wolf, a legend for all time. United Kingdom. https://books.google.com.mx/books?id=Q8GhS fZpYAoC \& printsec $=$ frontcover \&dq=lobos+ima genes\&hl=en\&sa=X\&ved=0ahUKEwi4-

IGl3svjAhUCRqwKHTWoCqAQ6AEITzAF\#v $=$ onepage $\& \mathrm{q} \& \mathrm{f}=$ false

Organización Panamericana para la Salud (2019) México ocupa el séptimo lugar a nivel mundial en meurtes por accidentes de tránsito" OPS

ttps://www.paho.org/mex/index.php?option=co m_content\&view=article\&id=552: mexicoocupa-septimo-lugar-nivel-mundial-muertesaccidentes-transito-ops\&Itemid $=0$

Peden, M., Cols. (2012) Informe mundial sobre la prevención de las lesiones en los niños. Organización Pnamericana de la Salud.

Suzuki, W. Fitzpatric B., Collins H. (2016) Healthy, Happy Life: a personal programa to active your graind and to everthing better.
Ruiz Olabuenaga, J. (1999) Metodología de la investigación cualitativa (pp. 11, 12) Bilbao, España: Universidad de Deusto.

Suárez, F. (2002) Intelectuales antifascistas. Madrid. Ed. Rialp 2002, pp. 315

Torres, L. (2002). Tratado de cuidados críticos y emergencias II. Editorial Aran Ediciones, Castelo, España, ISBN: 84-95-913-04-6. Fecha de consulta 13 de junio, 2019. https://books.google.com.mx/books?id=bZQZQhitGYC\&pg=PA1597\&dq=definici\%C $3 \% \mathrm{~B} 3 \mathrm{n}+\mathrm{de}+$ contusi $\% \mathrm{C} 3 \% \mathrm{~B} 3 \mathrm{n}+\mathrm{cerebral} \& \mathrm{hl}=\mathrm{e}$ $n \& s a=X \&$ ved $=0$ ahUKEwiK-

82BjefiAhVBba0KHRuYAHIQ6AEILTAA\#v= onepage \&q=definici $\% \mathrm{C} 3 \% \mathrm{~B} 3 \mathrm{n} \% 20 \mathrm{de} \% 20 \mathrm{cont}$ usi\%C3\%B3n\%20cerebral\&f=false

Yin, R. (1993) Applications of case study research, Sage Publishing Newbury, Park, CA

Universidad Autónoma de México, (2019) El Sistema Nervioso. www.facmed.unam.mx/Libro-NeuroFisio/06SistemaNervioso/CNS-

Overview/SistNervioso.html consultado: $1^{\circ}$. De julio, 2019.

Notmusa, S. A. de C. V. (2019) Lo que sucede en tu cuerpo cuando comes aguacate diariamente.

https://www.msn.com/es-mx/salud/nutricion/loque-sucede-en-tu-cuerpo-cuando-comesaguacate-diariamente/ss-

BBUgwSB? ocid=spartanntp\#image $=2$ 